\title{
Acute and modified rejection of heterotopic canine cardiac allotransplants studied by serial needle biopsy
}

\author{
P. W LEEDHAM, M. BA UM, and P. A. C U L LUM \\ Department of Morbid Anatomy, The London Hospital Medical College, London E.1 and \\ Department of Surgery, King's College Hospital Medical School, London S.E.5
}

Serial histological changes in heterotopic canine cardiac allografts are reported using a percutaneous needle biopsy technique. This procedure can be performed without general anaesthesia or major complications and gives a high success rate (over $98 \%$ ) with representative sampling of the organ.

A pattern of acute rejection is described and compares well with the findings in other orthotopic and heterotopic studies. Histological differences between a group of untreated dogs and a group receiving azathioprine and hydrocortisone, in amounts that would permit subacute rejection in treated human transplants, suggest that immunotherapy causes greater reduction in local cellular immunological activity than in graft necrosis. It is concluded that although major graft damage in acute and subacute rejection appears to be cell mediated other factors may also be concerned in the pathogenesis of graft necrosis.

Morphological features of acute rejection within a few days of transplantation are well known in many organs. Serial examination of these features in cardiac implants is made more difficult by problems of repeated biopsy both in the orthotopic and the heterotopic situation. The few studies that have been performed, using either an open or needle biopsy technique, report changes in acute rejection or in fully immunosuppressed animals. Simulation of a controlled rejection process as might be seen in the early stages of human transplantation has not been reported.

This report analyses 56 specimens obtained by percutaneous needle biopsy from 13 heterotopic canine cardiac allografts. The method is evaluated with reference to technical reliability, amount of tissue obtained, representative sampling, and its value in showing early rejection changes as compared with other studies. Cellular immunological activity and graft necrosis form distinct histological events which are compared in control dogs and in those given azathioprine and hydrocortisone.

\section{MATERIALS AND METHODS}

A modification of Mann's procedure was adopted and, under sterile conditions, donor hearts were obtained from mongrel dogs (weighing between $3.5 \mathrm{~kg}$ and $9.0 \mathrm{~kg}$ ) which had been anaesthetized with intravenous nembutal, $1 \mathrm{mg} / \mathrm{kg}$ body weight. The hearts were placed in saline at room temperature $\stackrel{0}{0}$ and a common atrium was formed following septal $\triangle$ excision with retention of the sino-atrial node. The heart was implanted into the right cervical pouch of $\overrightarrow{0}$ recipient greyhound dogs (weighing between 25.0 and $30.0 \mathrm{~kg}$ ) which were anaesthetized with intravenous nembutal, $0.5 \mathrm{mg} / \mathrm{kg}$ body weight, and allowed to breathe room air. The donor right pulmonary artery was joined to the proximal recipient external jugu-o lar vein and one donor brachiocephalic artery to the distal recipient carotid artery. The stumps of the remaining vessels were tied flush and the donor? heart was irrigated with saline before clamps were removed. AC. 110 ventricular defibrillation was per-윽 formed as necessary. One litre of Ringer's lactate was given intravenously to the recipient during ? surgery.

The study was divided into two parts with 10 을 animals in the first group and seven in the second. N No immunosuppressive drugs were given to animals. in group I (control dogs). Azathioprine, $3 \mathrm{mg} / \mathrm{kgN}$ body weight, and hydrocortisone, $6 \mathrm{mg} / \mathrm{kg}$ body weight, were given by intravascular injection during $\omega$ operation and on each morning of the following six< days to dogs in group II (treated dogs). No othefo drugs (including antibiotics) were used in this study.

Percutaneous left ventricular needle biopsies were ${ }^{?}$ taken daily in the first four dogs and on alternate days in the remainder using a Vim-Tru-Cut disposable needle. Biopsy was facilitated by $1 \%$ procaine local anaesthesia and a preliminary $5 \mathrm{~mm}$ stab $\overrightarrow{\mathrm{P}}$ wound using a No. 11 blade. The site and angle of $\frac{\varrho}{\sigma}$ 
the needle probe were varied to avoid previous biopsy areas and after removal of the needle bleeding was easily controlled by digital pressure. Percutaneous biopsies were also taken immediately before the animals were killed for subsequent comparison with blocks from the gross specimen after necropsy.

Half of the biopsy was used for tissue enzyme studies; the remainder was fixed in $10 \%$ formol saline and embedded in paraffin wax. After necropsy, when each heart was examined for patency of the major coronary vessels, the gross specimen was similarly fixed and blocks were taken from the right and left ventricles. Routine 3-5 $\mu$ sections were cut and stained by haematoxylin and eosin, and by methyl green pyronin to demonstrate pyroninophilic cells. Sudan black, reticulin, elastic van Gieson, PTAH, and Martius scarlet blue stains were used as required.

After a preliminary study of all histological sections in sequence, each was examined by one of us (P. W. L.) and scored, using a 0 to +++ system for the amount of rejection (mononuclear margination, presence of immunoblasts, microvascular disruption) and graft necrosis (muscle cell necrosis, polymorphonuclear infiltration). Each distinot feature was scored $0-3$, thus allowing a possible $0-9$ score for rejection and 0-6 score for graft necrosis on each biopsy. A general trend could be estimated by summating same day totals within each group of animals and plotting the average. Interstitial oedema was scored similarly $(0-3)$.
RESULTS

Two dogs in each group were excluded for technical reasons. The remaining eight dogs in group I survived for an average of 5.6 days (4-10 days). These studies were terminated because of increasing systemic disturbances manifested by malaise, anorexia, and, finally, vomiting. Five dogs in group II survived an average of 6.4 days (4-9 days) without systemic disturbance but the studies were terminated because of local wound infection and disruption.

The dogs were not visibly upset by the biopsy technique once confidence had been established. One needle was used throughout each study without reduction in efficiency. Two attempts were occasionally required to obtain an adequate biopsy. There were no local complications except for occasional bleeding which was controlled by digital pressure within a few minutes. Transitory ectopic beats were common during left ventricular puncture. On one occasion ventricular fibrillation ensued following accidental right atrial puncture and presumed bundle damage.

Fifty-six biopsies from 13 completed studies were available for assessment yielding tissue cylinders up to $10 \mathrm{~mm} \times 1.5 \mathrm{~mm}$. One showed pericardial tissue only, but in the remaining 55 , clear

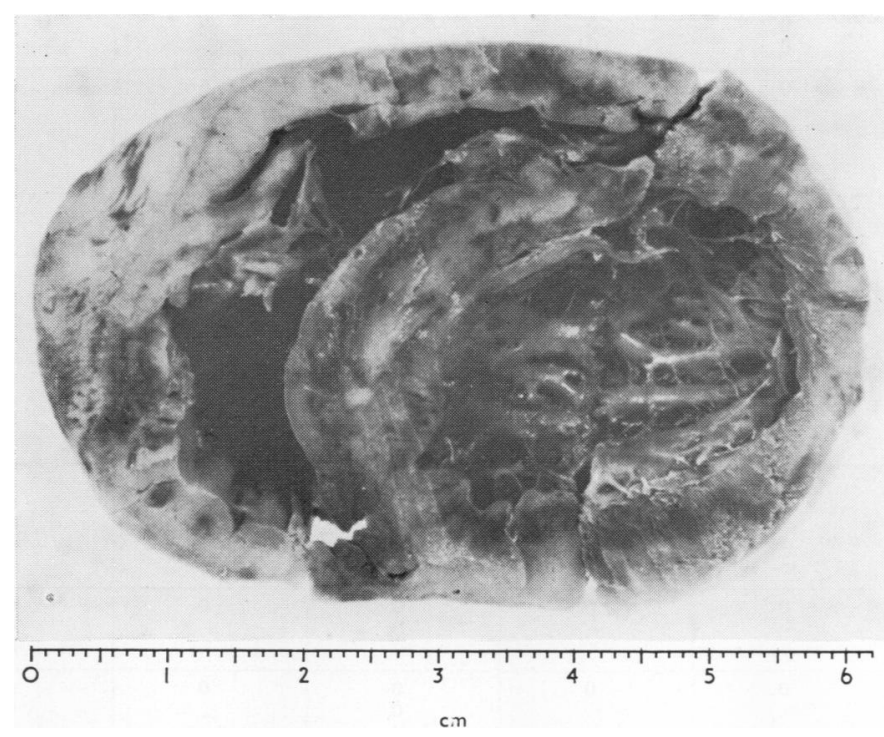

FIG. 1. Dog 3, day 6. Necropsy specimen of cardiac implant cut transversely and viewed from above (anterior surface at bottom of photograph). It shows numerous pale necrotic areas in the thickened oedematous walls of both right and left ventricles. 
histological evaluation of the myocardium and its microvasculature was possible; the endocardial surface was rarely seen. A comparison between the 13 terminal biopsies and post-mortem material revealed a close similarity in each case.

MACROSCOPIC APPEARANCES (GROUPS I AND II) The first dog in group I showed a green pericardial exudate, softened gangrenous myocardium, intraarterial and intracavity laminated thrombus, but no venous obstruction. All the other hearts had a patchy fibrinous pericardial exudate and were hard and swollen with a cut surface showing randomly distributed pale areas of necrosis and darker areas of congestion in both ventricles (Fig. 1). Laminated thrombus was present within the ventricular cavity in all cases but there was no evidence of occlusion of the main coronary arteries.

MICROSCOPIC APPEARANCES IN GROUP I (CONTROL DOGS) The findings are summarized in Table $I$.
Orientation of biopsy material is achieved by noting the pericardial surface but ignoring its histological features because of possible recipient $\frac{\pi}{\vec{T}}$ sepsis in this area. The first dog showed progres- $\triangle$ sive ischaemic necrosis without evidence of immunological cellular activity and it is therefore $\vec{O}$ eliminated from further analyses. The changes in the remaining dogs are similar to each other.

By the end of day 1 pericapillary interstitial oedema (Fig. 2) is present and increases progres- $\vec{x}$ sively thereafter. At the same time an occasional No intracapillary mononuclear cell with dense nuclear or chromatin, inconspicuous nucleoli, and a thin rim of cytoplasm is found. These cells, resem- $\rightarrow$ bling monocytes of peripheral blood, are often 은 closely applied to capillary endothelial cells (Fig. 2) ; they increase in number daily, being $\mathbb{D}$ joined gradually by other larger mononuclear cells with large open nuclei and a thin rim of 3 pyroninophilic cytoplasm (Fig. 3). By day 3-4 these changes are well developed and the capillaries of the myocardium, normally difficult to

T A B L E I

SUMMARY OF HISTOLOGICAL FINDINGS IN GROUP I DOGS

\begin{tabular}{|c|c|c|c|c|c|c|c|}
\hline \multirow{2}{*}{ Dog No. } & \multirow[b]{2}{*}{ Day } & \multicolumn{3}{|c|}{ Cellular Rejection } & \multicolumn{2}{|c|}{ Graft Necrosis } & \multirow[b]{2}{*}{ Oedema } \\
\hline & & $\begin{array}{l}\text { Mononuclear } \\
\text { Margination }\end{array}$ & Immunoblasts & $\begin{array}{c}\text { Microvascular } \\
\text { Disruption }\end{array}$ & Polymorphs & Necrosis & \\
\hline 1 & $\begin{array}{l}1 \\
2 \\
3 \\
4\end{array}$ & $\begin{array}{l}0 \\
0 \\
0 \\
0\end{array}$ & $\begin{array}{l}0 \\
0 \\
0 \\
0\end{array}$ & $\begin{array}{l}0 \\
0 \\
0 \\
0\end{array}$ & $\begin{array}{r}+ \\
\mathbf{0} \\
+ \\
++\end{array}$ & $\begin{array}{r}0 \\
++ \\
++ \\
+\end{array}$ & $\begin{array}{r}+ \\
+ \\
++ \\
++\end{array}$ \\
\hline 2 & $\begin{array}{l}1 \\
2^{1} \\
3 \\
4 \\
5\end{array}$ & $\begin{array}{l}0 \\
\pm \\
0 \\
\pm \\
+\end{array}$ & $\begin{array}{r}0 \\
+ \\
0 \\
++ \\
++\end{array}$ & $\begin{array}{r}0 \\
0 \\
0 \\
+ \\
++\end{array}$ & $\begin{array}{r}0 \\
0 \\
+ \\
++ \\
++\end{array}$ & $\begin{array}{r}0 \\
0 \\
+ \pm \\
++ \\
++\end{array}$ & $\begin{array}{r}0 \\
+ \\
+ \\
++ \\
++\end{array}$ \\
\hline 3 & $\begin{array}{l}1 \\
2 \\
3 \\
4 \\
5 \\
6\end{array}$ & $\begin{array}{r}t \\
\dot{+} \\
+ \\
++ \\
++ \\
++\end{array}$ & $\begin{array}{r}0 \\
\pm \\
+ \\
++ \\
++t \\
++t\end{array}$ & $\begin{array}{r}\mathbf{0} \\
\mathbf{0} \\
\mathbf{0} \\
++ \\
+++ \\
+++\end{array}$ & $\begin{array}{r}0 \\
0 \\
+ \\
+++ \\
++t \\
+++\end{array}$ & $\begin{array}{r}0 \\
0 \\
+ \\
+++ \\
+++ \\
++\end{array}$ & $\begin{array}{r}t \\
+ \\
+ \\
++t \\
++t \\
++t\end{array}$ \\
\hline 6 & $\begin{array}{l}1 \\
2 \\
3 \\
4 \\
5\end{array}$ & $\begin{array}{r}+ \\
+ \\
\pm \\
+ \\
+\end{array}$ & $\begin{array}{r}\mathbf{0} \\
0 \\
\frac{ \pm}{+} \\
++t\end{array}$ & $\begin{array}{r}\mathbf{0} \\
\mathbf{0} \\
\mathbf{0} \\
\mathbf{0} \\
++ \\
\end{array}$ & $\begin{array}{r}0 \\
0 \\
0 \\
+ \\
++\end{array}$ & $\begin{array}{r}\mathbf{0} \\
\mathbf{0} \\
\mathbf{0} \\
\mathbf{0} \\
++ \\
\end{array}$ & $\begin{array}{r} \pm \\
\pm \\
+ \\
+ \\
+\end{array}$ \\
\hline 7 & $\begin{array}{r}2 \\
4 \\
6 \\
8 \\
10 \\
\end{array}$ & $\begin{array}{c}+ \\
+ \\
+ \\
+ \\
<-\end{array}$ & $\begin{array}{c}+ \\
++ \\
+++ \\
+++ \\
\text { extensive }\end{array}$ & $\begin{array}{r}0 \\
+ \\
+++ \\
+++ \\
\text { necrosis }\end{array}$ & $\begin{array}{r}0 \\
+ \\
+ \\
++\end{array}$ & $\begin{array}{r}0 \\
0 \\
+ \\
++\end{array}$ & $\begin{array}{r}+ \\
++ \\
++ \\
+++ \\
\end{array}$ \\
\hline 8 & $\begin{array}{l}1 \\
3 \\
5\end{array}$ & $\begin{array}{r}0 \\
+ \\
+\end{array}$ & $\begin{array}{r}0 \\
+ \\
+\end{array}$ & $\begin{array}{r}0 \\
0 \\
++ \\
\end{array}$ & $\begin{array}{r}0 \\
+ \\
+++\end{array}$ & $\begin{array}{r}0 \\
0 \\
+++\end{array}$ & $\begin{array}{r}+ \\
+ \\
++\end{array}$ \\
\hline 9 & $\begin{array}{l}1 \\
3 \\
5 \\
\end{array}$ & $\begin{array}{r}0 \\
+ \\
++ \\
\end{array}$ & $\begin{array}{r}0 \\
+ \\
++ \\
\end{array}$ & $\begin{array}{r}0 \\
0 \\
++ \\
\end{array}$ & $\begin{array}{r}0 \\
\pm \\
\pm\end{array}$ & $\begin{array}{r}0 \\
0 \\
+++ \\
\end{array}$ & $\begin{array}{r}t \\
+ \\
++\end{array}$ \\
\hline 10 & $\begin{array}{l}1 \\
3 \\
5\end{array}$ & $\begin{array}{r}\mathbf{0} \\
\mathbf{0} \\
++\end{array}$ & $\begin{array}{r}\mathbf{0} \\
\mathbf{0} \\
++\end{array}$ & $\begin{array}{r}\mathbf{0} \\
\mathbf{0} \\
++\end{array}$ & $\begin{array}{r}0 \\
\pm \\
+\end{array}$ & $\begin{array}{r}\mathbf{0} \\
\mathbf{0} \\
++\end{array}$ & $\begin{array}{r}+ \\
+ \\
+\end{array}$ \\
\hline
\end{tabular}

Mainly pericardial tissue. 


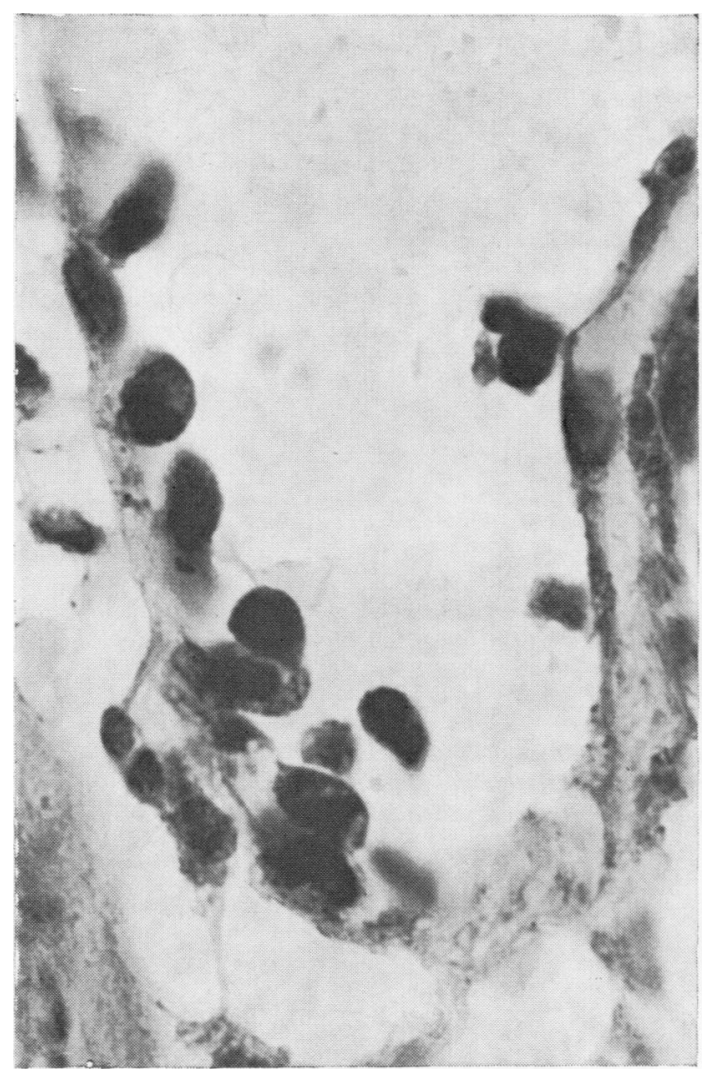

FIG. 2. Dog 6, day 1. Part of a capillary containing several mononuclear cells. Some of these are adherent to the endothelium. There is pericapillary oedema. (Methyl green pyronin $\times 1180$.)

see, are well delineated by this process. These cells infiltrate extensively through the capillary walls and among heart muscle fibres where occasional very large cells with big vesicular nuclei, prominent often multiple nucleoli, and a rim of densely pyroninophilic cytoplasm are also present (Fig. 4); some of these cells are seen in mitosis (Fig. 4). This group of cells are regarded as immunoblasts' (Dameshek, 1963).

While these cellular events are developing the walls of the arterioles and capillaries show changes which are also well developed by day 3-4. In arterioles the endothelial cells appear to round up and lift off the underlying tissues; in some places the mononuclear cells are in close apposition (Fig. 5). A similar change occurs in capillary endothelium which contributes to the passage of mononuclear cells into the parenchyma.

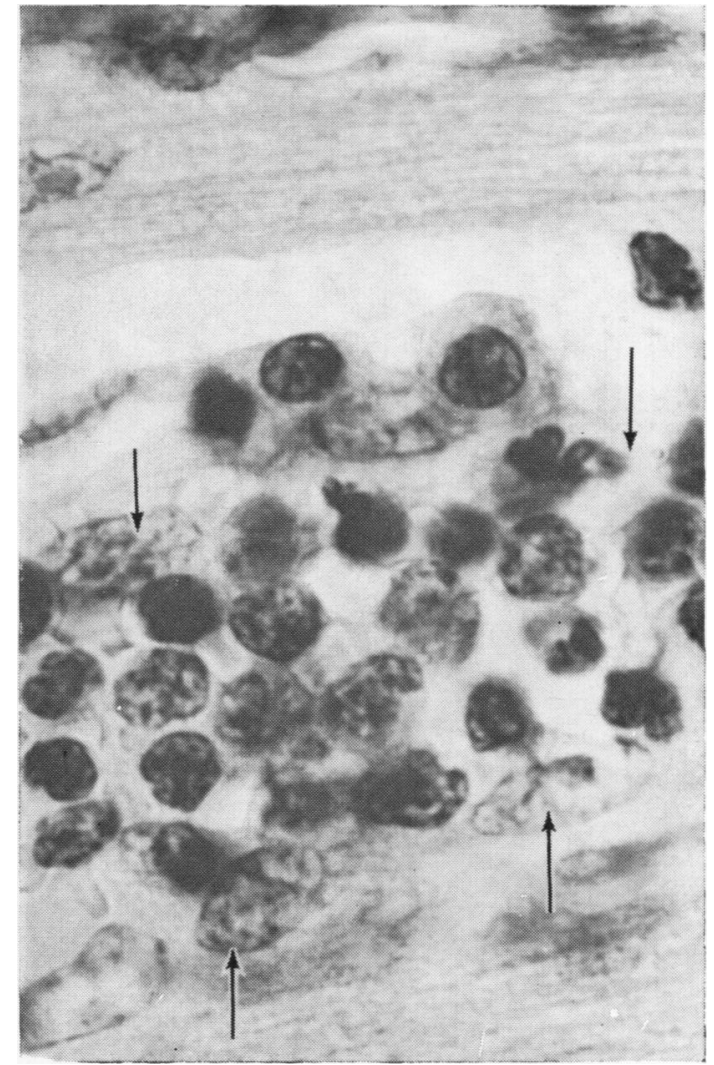

FIG. 3. Dog 7, day 4. Immature mononuclear cells are distending a capillary, the margins of which are poorly defined (arrows). Some cells have escaped into the interstitium. (Haematoxylin and eosin $\times 1180$.)

Thus by day 4-5 there is a well-developed cellular response composed of lymphocytes, plasma cells, and numerous immature mononuclear cells in and around vessels of all sizes (Fig. 6). Although of varying intensity this response is present in all areas of the myocardium examined. The capillary walls become almost impossible to identify and are disrupted in places.

Muscle cell necrosis is not seen until day 3 (Fig. 7). Small initial foci are related to the mononuclear infiltrate as it extends into the myocardium but larger random areas of frank infarction seen in terminal biopsies and at necropsy show no evidence of previous mononuclear infiltration. Large numbers of polymorphonuclear cells are seen in association with muscle cell necrosis but not elsewhere. Occasional capillaries contain small fibrin thrombi in the terminal stages. 


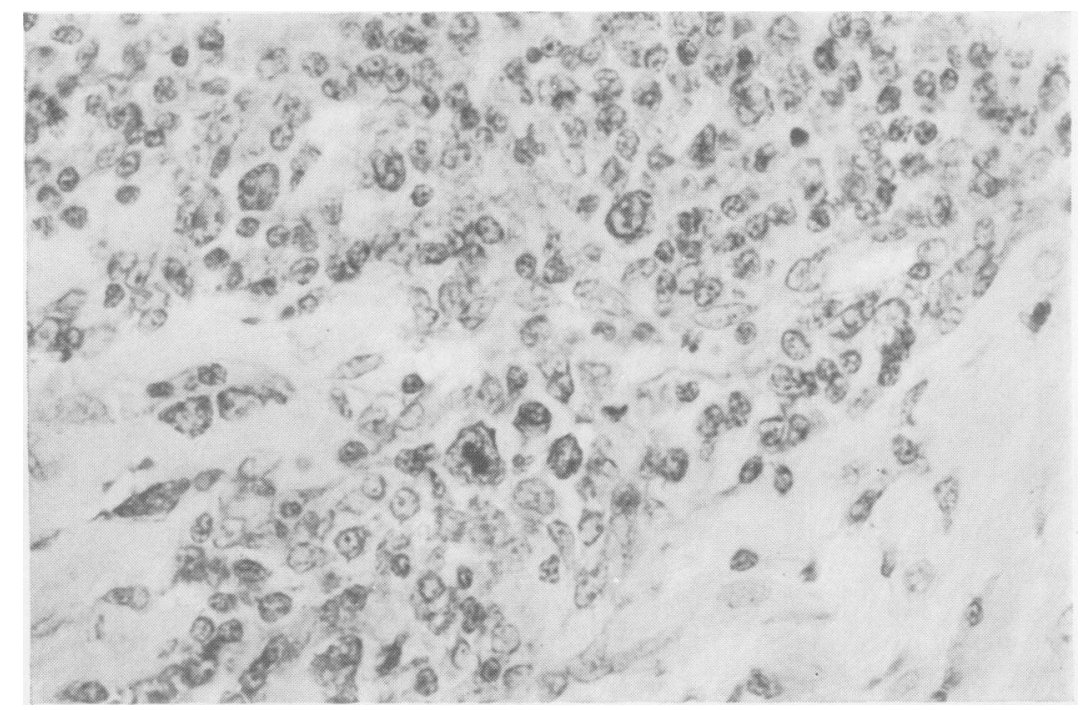

FIG. 4. Dog 3, day 4. There is extensive infiltration of the myocardium by immature mononuclear cells. Some of these cells are regarded as immunoblasts having large vesicular nuclei, prominent nucleoli, and a dense rim of pyroninophilic cytoplasm; one of them is shown in mitosis. (Methyl green pyronin $\times 470$.)

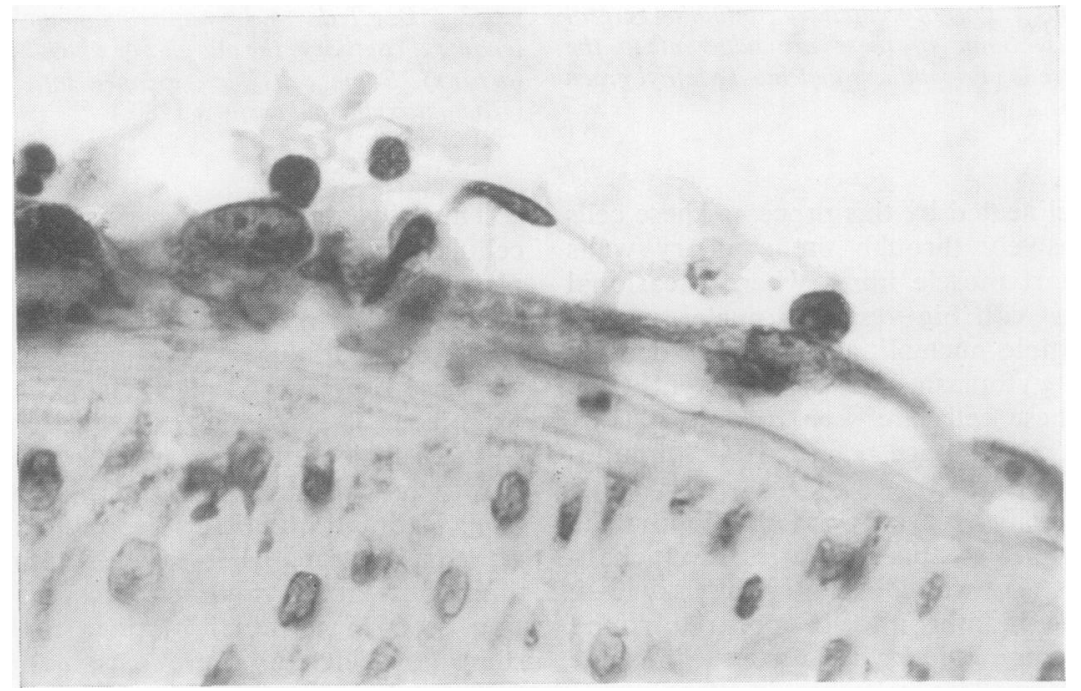

FIG. 5. Dog 9, day 3. Luminal surface of a small artery in which the endothelial cells are rounding up and lifting off the underlying smooth muscle. Occasional mononuclear cells are closely applied to the endothelial cells. (Methyl green pyronin $\times 1180$.) 


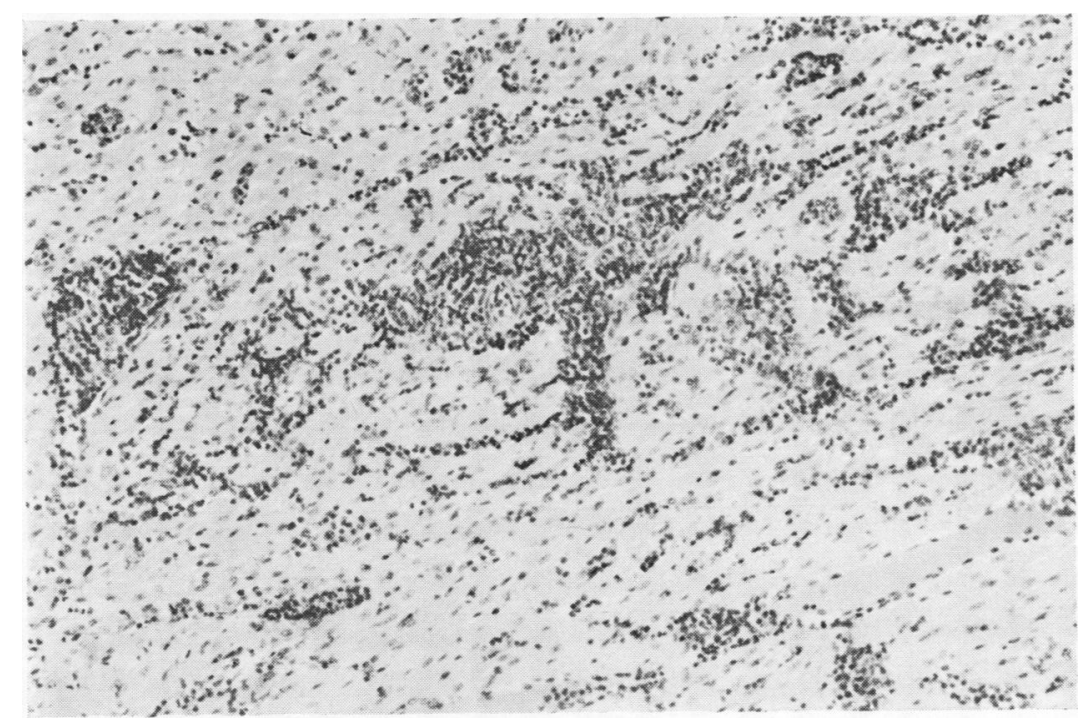

FIG. 6. Dog 7, day 4. Shows mononuclear cells of varying maturity within and around vessels and extending into the myocardium. Capillaries normally difficult to see are well defined by this process. (Haematoxylin and eosin $\times 118$.)

Arteritic changes including fibrinoid necrosis are not seen and there is no hyperplasia of vessel walls. Adjacent to areas of infarction attempts at inflammatory repair are apparent with young granulation tissue and fibroblasts.

MICROSCOPIC APPEARANCES IN GROUP II (TREATED DOGS) The findings are given in Table II, and the composite trends of immunological cellular activity and necrosis up to the fifth day within each group are compared in Figs. 8 and 9 using the scoring system outlined above. The same basic structural changes occur in these dogs treated by partial immunosuppressive therapy but the timing and severity are different. Cellular rejection, as indicated by mononuclear margination, presence of immunoblasts, and microvascular disruption, develops later and is less severe, so that by the fifth day the intensity is about one-third of that seen in control dogs (Fig. 8). Ischaemic damage, as indicated by muscle cell necrosis and polymorph infiltration, is also reduced but to a lesser extent. The average amount seen is still more than half that present in control dogs. Oedema is excluded as a criterion in this comparison because, although present in the early stages of rejection, it is also a prominent feature in tissue necrosis and the acute inflammatory reaction which follows. Unfortu- nately these apparent differences cannot be subjected to rigorous statistical analysis in a histological assessment of this kind.

\section{DISCUSSION}

Previous serial histological studies of cardiac allografts have been hindered by the difficulty in obtaining repeated samples of myocardium. Most of these studies have required either open biopsies under general anaesthesia (Rowlands, Vanderbeek, Seigler, and Ebert, 1968) or sacrifice of animals at planned intervals (Wesolowski and Fennessey, 1953 ; Kosek, Hurley, and Lower, 1968). Others have included only terminal necropsy material (Blumenstock et al., 1963 ; Lower, Dong, and Shumway, 1965 ; Leandri, 1967 ; Downie, 1953 ; Reemtsma, 1964) or give morphological changes little prominence (Reemtsma et al., 1962; Hardy et al., 1966). Recently a biopsy technique using a Vim Silverman needle has been reported (Chiba et al., 1962; Tennenbaum, St. Pierre, and Vasko, 1969). This needle has been improved to form the Vim-TruCut disposable needle used in this study and recently in a study of liver biopsies (Rake, MurrayLyon, Ansell, and Williams, 1969).

The present series establishes that excellent histology may regularly be obtained as shown 
T A B L E I I

SUMMARY OF HISTOLOGICAL FINDINGS IN GROUP II DOGS

\begin{tabular}{|c|c|c|c|c|c|c|c|}
\hline \multirow{2}{*}{ Dog. No. } & \multirow{2}{*}{ Day } & \multicolumn{3}{|c|}{ Cellular Rejection } & \multicolumn{2}{|c|}{ Graft Necrosis } & \multirow[b]{2}{*}{ Oedema } \\
\hline & & $\begin{array}{l}\text { Mononuclear } \\
\text { Margination }\end{array}$ & Immunoblasts & $\begin{array}{c}\text { Microvascular } \\
\text { Disruption }\end{array}$ & Polymorphs & Necrosis & \\
\hline 12 & $\begin{array}{l}1 \\
3 \\
5 \\
6 \\
\end{array}$ & $\begin{array}{l} \pm \\
\pm \\
\pm \\
<- \\
\end{array}$ & $\begin{array}{l}0 \\
+ \\
+ \\
\text { extensive }\end{array}$ & $\begin{array}{r}\text { o }^{\mathbf{0}} \\
\text { necrosis }^{+}\end{array}$ & $\begin{array}{r} \pm \\
+ \\
+\end{array}$ & $\begin{array}{r} \pm \\
+ \\
+\end{array}$ & $\begin{array}{r} \pm \\
+ \\
++ \\
\end{array}$ \\
\hline 13 & $\begin{array}{l}1 \\
3 \\
5 \\
7 \\
8 \\
\end{array}$ & $\begin{array}{l}0 \\
0 \\
0 \\
+ \\
+ \\
\end{array}$ & $\begin{array}{r}0 \\
+ \\
+ \\
++ \\
+\end{array}$ & $\begin{array}{r}0 \\
0 \\
0 \\
+ \\
++\end{array}$ & $\begin{array}{r}0 \\
+ \\
++ \\
+ \\
++\end{array}$ & $\begin{array}{c}{ }^{0} \\
+ \\
+ \\
+ \\
+ \\
+\end{array}$ & $\begin{array}{r}0 \\
++ \\
+t+ \\
++ \\
++t\end{array}$ \\
\hline 14 & $\begin{array}{l}1 \\
3 \\
4\end{array}$ & $\begin{array}{l}+ \\
+ \\
+\end{array}$ & $\begin{array}{l}\mathbf{0} \\
\mathbf{0} \\
+ \\
\end{array}$ & $\begin{array}{l}0 \\
0 \\
0\end{array}$ & $\begin{array}{r}\mathbf{0} \\
0 \\
++\end{array}$ & $\begin{array}{l}0 \\
0 \\
0\end{array}$ & $\begin{array}{r} \pm \\
+ \\
++\end{array}$ \\
\hline 15 & $\begin{array}{l}0 \\
1 \\
3 \\
5 \\
\end{array}$ & $\begin{array}{r}0 \\
0 \\
+ \\
+ \\
\end{array}$ & $\begin{array}{l}\mathbf{0} \\
\mathbf{0} \\
+ \\
+ \\
\end{array}$ & $\begin{array}{r}\mathbf{0} \\
\mathbf{0} \\
\mathbf{0} \\
+ \\
\end{array}$ & $\begin{array}{l}0 \\
+ \\
+ \\
\pm\end{array}$ & $\begin{array}{l}\mathbf{0} \\
\mathbf{0} \\
\mathbf{0} \\
\pm \\
\end{array}$ & $\begin{array}{l}0 \\
+ \\
+ \\
+\end{array}$ \\
\hline 17 & $\begin{array}{l}0 \\
1 \\
3 \\
5 \\
7 \\
9\end{array}$ & $\begin{array}{l}\mathbf{0} \\
\mathbf{0} \\
\mathbf{0} \\
\pm \\
\pm \\
+\end{array}$ & $\begin{array}{r}\mathbf{0} \\
\mathbf{0} \\
\mathbf{0} \\
\pm \\
\pm \\
+ \pm \\
+\end{array}$ & $\begin{array}{l}\mathbf{0} \\
0 \\
0 \\
\pm \\
\pm \\
+\end{array}$ & $\begin{array}{r}\mathbf{0} \\
0 \\
0 \\
++ \\
+++ \\
+++\end{array}$ & $\begin{array}{r}0 \\
0 \\
0 \\
++ \\
+++ \\
+++\end{array}$ & $\begin{array}{r}0 \\
0 \\
+ \\
++ \\
+++ \\
+++\end{array}$ \\
\hline
\end{tabular}

by clear, undistorted myocardial specimens in more than $98 \%$ of biopsies. There was good correlation between the appearances seen in terminal needle samples and necropsy material, indicating that needle sampling is representative. Movement of the heart does not impede biopsy, and implant function is not affected provided the conducting system and great vessels are avoided.

The results correspond with changes described in untreated orthotopic canine heart transplants by Kosek et al. (1968) and Bieber, Stinson, and Shumway (1969). They found similar oedema, margination of mononuclear cells, swelling of endothelium, and cells called 'plasmablasts' which appear to be the same as 'immunoblasts'. There are some differences in that they report more fibrin thrombi and early arteritis, which we did not see. Mononuclear cells are described attacking and destroying individual myocardial fibres, a finding which we could not substantiate although in the later stages the myocardium is so heavily infiltrated by mononuclear cells that this cannot be excluded. However, the basic agreement between the findings indicates that the present technique is a valid method for studying cardiac rejection. In addition, it shows that heterotopic hearts undergo changes similar to orthotopic hearts.

Some of the earliest histological changes in the present series differ from those described by other workers. Chiba et al. (1962), Rowlands et al. (1968), and Tennenbaum et al. (1969) give prominence to a perivascular lymphocytic infiltrate without mention of immunoblast-like cells. In one series (Chiba et al., 1962), multinucleate giant cells resembling Aschoff cells are recorded 19 hours after transplant; these were not seen $\stackrel{\odot}{\varnothing}$ in the present study. Most agree that the end result within seven days is extensive myocardial necrosis and mononuclear cell infiltration, mainly of perivascular distribution (Reemtsma, 1964 ; Lower et al., 1965 ; Chiba et al., 1962 ; Rowlands et al., 1968). A pericardial and endocardial origin of the rejection process has been reported (Leandri, 1967), but the present study suggests $\times$ an even distribution of the rejection process, cen- $\frac{3}{3}$ tred on small vessels and capillaries, throughout the myocardium. We feel that the changes at the $\frac{\circ}{3}$ pericardial surfaces are often confused by the presence of an acute inflammatory response to $\frac{1}{7}$ trauma or infection and should be ignored.

Our findings support the view that circulating host cells entering the grafted heart play a large $N$ part in acute rejection. The subsequent oblitera- $N$ tion of the capillary network by cellular infiltrate containing immunoblasts has been reported $\omega$ in acute cardiac rejection on a few occasions? (Kosek et al., 1968 ; Bieber et al., 1969) but is a읃 well-established sequence in acute rejection of the kidney (Kountz et al., 1963 ; Williams, Williams, Kountz, and Dempster, 1964 ; Porter et al., 1964). It would seem logical that rejection phenomena in all vascular organs would follow a similar pattern. $\frac{?}{8}$ The changes appear to support the view that a 


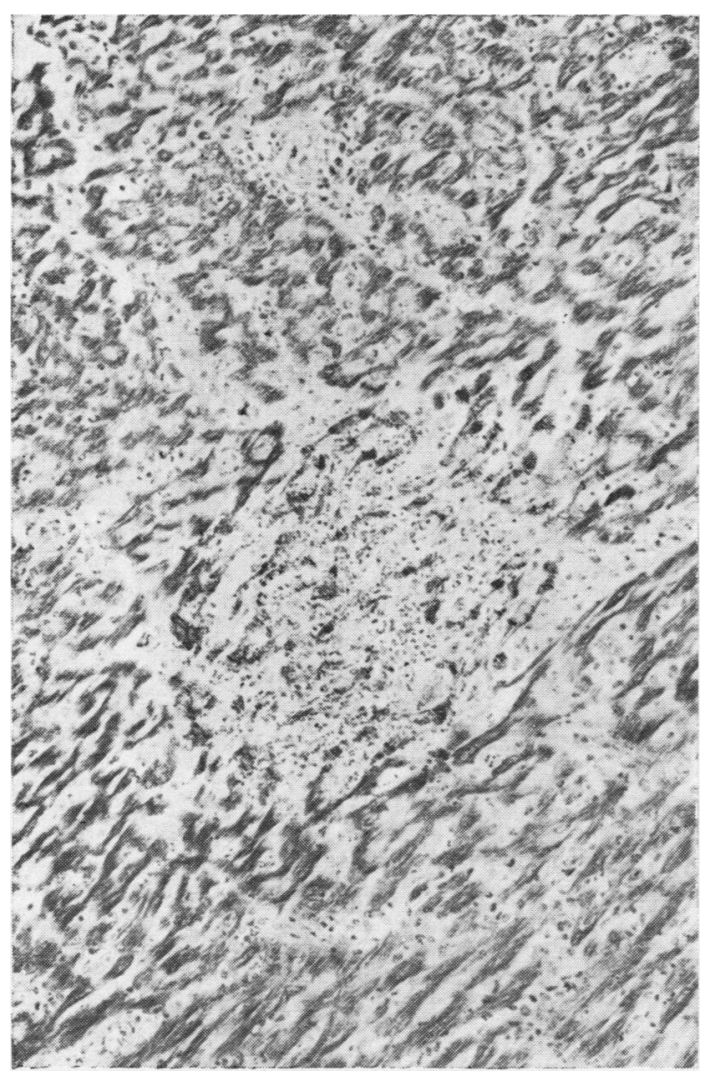

FIG. 7. Dog 2, day 3. A small area of muscle cell necrosis with fragmented fibres showing loss of staining properties. The necrotic focus is infiltrated by polymorphonuclear leucocytes. The surrounding myocardium is viable but oedematous with some mononuclear cell infiltration. (Phosphotungstic acid haematoxylin $\times 118$.)

major consequence of acute rejection is ischaemia caused by extensive microvascular disruption (Dempster, 1968) ; occlusion of major vessels has not been seen in any of the reported series of acute cardiac rejection.

Other mechanisms of graft necrosis have been proposed, and a direct action of mononuclear cells on the myocardium is probably the most important of these (Kosek et al., 1968). Ramos et al. (1963) described increased vascular permeability within the first four days after transplantation, antedating the cellular response and corresponding well with the early oedema seen in this series. They suggested that humoral factors play an initial role but there is little evidence to support this in allografts although it is well known in xenografts (Myburgh, 1968).
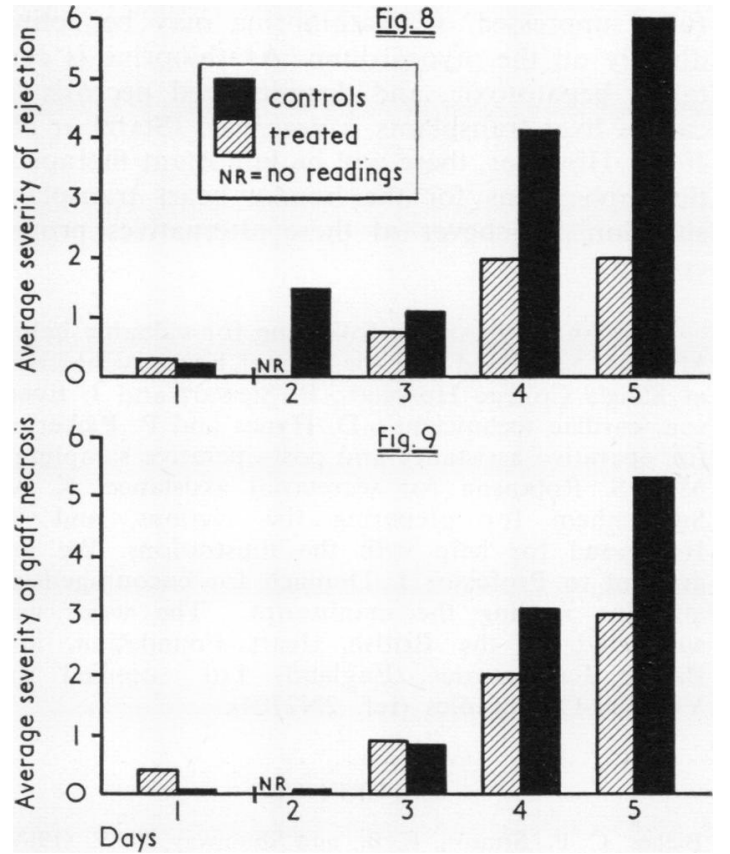

FIG. 8. Shows the general trend in the development of cellular rejection changes in treated and control groups. The scale has been shortened from 0-9 to 0-6 as none of the daily averages fell above this level in the first five days.

FIG. 9. Shows the general trend in the development of graft necrosis in treated and control groups.

In comparing the results from the two groups of dogs it is not surprising that the cellular parameters of rejection are reduced in the presence of immunosuppressive therapy (Fig. 8) since it is well known that these agents act directly in suppressing cell-mediated response (Porter, 1966). The systemic effects of acute rejection are also absent in group II. However, ischaemic damage is apparently reduced to a lesser degree in treated grafts (Fig. 9). These findings of persistent graft necrosis in treated dogs are supported by continuing abnormalities in serum enzymes, tissue LDH isoenzymes, and lactate metabolism in this group of animals (Cullum et al., in preparation), but the explanation remains speculative.

A reduced cellular response in treated dogs may still produce enough microvascular disruption to cause severe ischaemic damage and this would suggest that a cellular rejection response above a critical level will still initiate massive ischaemic damage. Alternatively, the humoralantibody response may have been less success- 
fully suppressed or azathioprine may be acting directly on the myocardium. Azathioprine is certainly hepatotoxic, and drug-induced necrosis in canine liver transplants is described (Starzl et al., 1965). However, there will be important therapeutic implications for the human heart transplant situation, whichever of these alternatives proves correct.

We wish to thank the following for valuable help: Miss M. Sandiford and the animal house technicians at King's College Hospital ; P. Stewart and J. Everson, cardiac technicians; D. Hynes and P. Pickering for operative assistance and post-operative sampling ; Miss S. Robinson for secretarial assistance, K. V. Swettenham for preparing the sections, and $\mathbf{R}$. Hammond for help with the illustrations. We are grateful to Professor I. Doniach for encouragement and for reading the manuscript. The work was supported by the British Heart Foundation, and Baxter Laboratories (England) Ltd. supplied the Vim-Tru-Cut needles (ref. 2N2704).

\section{REFERENCES}

Bieber, C. P., Stinson, E. B., and Shumway, N. E. (1969). Pathology of the conduction system in cardiac rejection. Circulation, 39, 567.

Blumenstock, D. A., Hechtman, H. B., Collins, J. A., Jaretzki, A., Hosbein, J. D., Zingg, W., and Powers, J. H. (1963). Prolonged survival of orthotopic homotransplants of the heart in animals treated with Methotrexate. J. thorac. cardiovasc. Surg., 46, 616.

Chiba, C., Wolf, P. L., Gudbjarnason, S., Chrysohou, A., Ramos, H., Pearson, B., and Bing, R. J. (1962). Studies on the transplanted heart. Its metabolism and histology. J. exp. Med., 115, 853.

Dameshek, W. (1963). 'Immunoblasts' and 'immunocytes'an attempt at a functional nomenclature. Blood, 21, 243.

Dempster, W. J. (1968). Human heart transplantation (Letter). Brit. med. J., 2, 695.

Downie, H. G. (1953). Homotransplantation of the dog heart. Arch. Surg., 66, 624.

Hardy, J. D., Chavez, C. M., Eraslan, S., Adkins, J. R., and Williams, R. D. (1966). Heart transplantation in dogs. Procedures, physiologic problems, and results in 142 experiments. Surgery, 60, 361.
Kosek, J. C., Hurley, E. J., and Lower, R. R. (1968). Histo-O pathology of orthotopic canine cardiac homografts. Lab. Invest., 19, 97.

Kountz, S. L., Williams, M. A., Williams, P. L., Kapros, C., and Dempster, W. J. (1963). Mechanism of rejection of homotransplanted kidneys. Nature (Lond.), 199, 257.

Leandri, J. (1967). Some histological features of canine cardiac transplants. Thorax, 22, 397.

Lower, R. R., Dong, E., and Shumway, N. E. (1965). Longterm survival of cardiac homografts. Surgery, 58, 110 .

Myburgh, J. A. (1968). Humoral antibodies and transplantation immunity. S. Afr. J. Surg., 6, 41.

Porter, K. A. (1966). Tissue transplantation. In: Recentiv Advances in Pathology, 8th ed. (ed. C. V. Harrison) p. 256. Churchill, London.

- Joseph, N. H., Rendall, J. M., Stolinski, C., Hoehn, R. J., and Calne, R. Y. (1964). The role of lymphocytes in the rejection of canine renal homotransplants. Lab.ح Invest., 13, 1080.

Rake, M. O., Murray-Lyon, I. M., Ansell, I. D., and Williams, R. (1969). Improved liver-biopsy needle. Lancet, 2, 1283.

Ramos, H. R., Chiba, C., Schollmeyer, P., Wolf, P. L. Pearson, B., and Bing, R. J. (1963). The presence of humoral factors in homograft rejection of the transplanted heart. Transplantation, 1, 284.

Reemtsma, K. (1964). The heart as a test organ in trans plantation studies. Ann. N.Y. Acad. Sci., 120, 778.

-, Williamson, W. E., Iglesias, F., Pena, E., Sayegh, S. F., and Creech, O. (1962). Studies in homologous canine heart transplantation: prolongation of survival with $क \overline{5}$ folic acid antagonist. Surgery, 52, 127.

Rowlands, D. T., Vanderbeek, R. B., Seigler, H. F., and Ebert, P. A. (1968). Rejection of canine cardiac allo grafts. Amer. J. Path., 53, 617.

Starzl, T. E., Marchioro, T. L., Porter, K. A., Taylor, P. D., Faris, T. D., Herrmann, T. J., Hlad, C. J., and Waddell? W. R. (1965). Factors determining short- and long-termo survival after orthotopic liver homotransplantation in the dog. Surgery, 58, 131.

Tennenbaum, J. I., St. Pierre, R. L., and Vasko, J. S. (1969) Early detection of canine heart allograft rejection. Arch $\underset{x}{ }$ Surg., 99, 753.

Wesolowski, S. A., and Fennessey, J. F. (1953). Pattern o? failure of the homografted canine heart. Circulation, $8 \AA$ 750.

Williams, P. L., Williams, M. A., Kountz, S. L., and Dempster, W. J. (1964). Ultrastructural and haemodynamic studies in canine renal transplants. J. Anat. (Lond.), 98, 545 . 